\title{
Role of Herbs in Cancer
}

\begin{abstract}
Received:
01.03.2019

Accepted:

25.03.2019

Keywords

Cancer;

Malignant;

Benign; Vinca;

Turmeric.
\end{abstract}

\author{
Navdeep Singh *1, Pooja Sharma ${ }^{1,2}$, Dinesh Kumar ${ }^{1}$ \\ ${ }^{1}$ Sri Sai College of Pharmacy, Manawala, Amritsar-143115, Punjab, India \\ ${ }^{2}$ Department of Pharmaceutical Sciences and Drug Research, Punjabi University Patiala, Punjab, India
}

Address for Correspondence: Navdeep Singh; dineshkumargndu@gmail.com

\begin{abstract}
Cancer is a disease that includes abnormal cell division in an uncontrolled manner which further leads to destruction of body tissues. Cancer is classified by the type of cell and may vary by carcinoma, sarcoma, and lymphoma. Approximately, 8.2 million people are killed every single year due to cancer. The main causes that cause cancer are obesity, poor diet, intake of alcohol and tobacco etc. There may be symptoms that include abnormal bumps, fever, night sweats or in some cases leads to weight loss and change in bowel movements. Natural drugs that treat cancer are Vinca rosea, Ginseng, Turmeric, Dandelion. These plants act as anti-cancer agents and helps prevent the cancer in patients. (C) 2019 iGlobal Research and Publishing Foundation. All rights reserved.
\end{abstract}

Cite this article as: Singh, S.; Sharma, P.; Kumar, D. Role of Herbs in Cancer. Indo Global J. Pharm. Sci., 2019; 9(2Suppl.): 160. DOI: http://doi.org/10.35652/IGJPS.2019.92S58 .

Indo Global Journal of Pharmaceutical Sciences( ISSN 2249 1023; CODEN- IGJPAI; NLM ID: 101610675) indexed and abstracted in CrossRef (DOI Enabling), UGC CARE Journal List, EMBASE(Elsevier), National Library of Medicine (NLM) Catalog, ResearchGate, Publons, CAS (ACS), Index Copernicus, Google Scholar and many more. For further details, visit http://iglobaljournal.com

This is a special issue as an outcome of 'RAPSCON-2019' sponsored by APTI and organized by Sri Sai College of Pharmacy, Manawala, Amritsar, Punjab, India. Relaxation offered in journal format. 